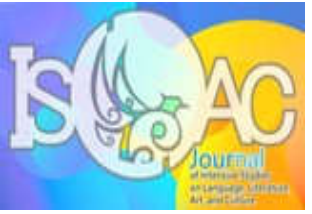

ISLLAC : Journal of Intensive Studies on Language, Literature, Art, and Culture

Volume 2 Issue. 1, 2018

Journal homepage : http://journal2.um.ac.id/index.php/jisllac

\title{
VOCABULARY OPTIONS OF POWER EXPERIENTIAL VALUE OF BUGIS FEMALE TEACHER IN INDONESIAN LANGUAGE SUBJECT
}

\author{
Asri Ismail, Anang Santoso, Sunoto* \\ Postgraduate of Malang State University (UM), Indonesia
}

\begin{tabular}{ll} 
A R T I C L E I N F O & A B S T R A C T \\
\cline { 2 - 3 } $\begin{array}{l}\text { Keyword: } \\
\text { Vocabulary Options, }\end{array}$ & $\begin{array}{l}\text { This article reviews the vocabulary options in the experiential values of Bugis female } \\
\text { teachers in teaching Indonesian language in the classroom. In this research, teacher's } \\
\text { Experiential Value, }\end{array}$ \\
$\begin{array}{l}\text { Powers of Bugis Female } \\
\text { Teachers, }\end{array}$ & $\begin{array}{l}\text { authorization. These authorities power are traced through the vocabulary choices seen in } \\
\text { the experiential value. In the text, the discourse analysis model used Norman Fariclough } \\
\text { Indonesian Language }\end{array}$ \\
$\begin{array}{l}\text { Learning, } \\
\text { Critical discourse analysis }\end{array}$ & $\begin{array}{l}\text { convincing, domination, and control vocabularies. The results found that the resistance of } \\
\text { Bugis female teachers in class discourse was a dissatisfaction form of the patriarchal } \\
\text { tradition prevailing in society. }\end{array}$
\end{tabular}

\section{INTRODUCTIONS}

Power never escapes from the patriarchal culture, a culture that has indirectly distinguished the role of women and men in the social context (Gay \& Susanti, 2017). This role presents men as the dominating side of the women that we call as the gender events. The male hegemony also against the female in various communications, for example through language contact. Language is not only a means of communication, either in oral or written form. But transmitting information is clearly not the only reason we use language and there are many linguistic choices we make everyday that have no impact on the transmission/delivery information at all (Thomas \& Wareing, 1999: 13). However, there is no complete production process and interpretation by ignoring the process of dependence on the social background that leads us to the notion that language is a social practice (Fairclough 1989: 27). So, language is the embodiment of social practice.

The power of men against women occurs in every region in Indonesia. In the province of South Sulawesi, in terms of determining the ruler is done by searching the line is bilateral. From the pedigree that every son of a ruler, male or female, the first or last child, can replace him, although in reality it is usually elected men (Caldwell, 1995: 404). In terms of interaction, the Bugis tribe in South Sulawesi, men are generally treated with respect by women but not vice versa, with the implicit display of meaning implying that men are socially dominant (Milliar, 1983: 477).

The general ideology of women has emphasized to the seclusion and marginalization value, so as the impact is the exclusion of women in certain fields and the preeminence of women's females. This understanding influences the Bugis female always expressed the greatness of their husband as the head of the family. According to Syamsudduha (2014: 281) the tradition in Bugis society, that is a very taboo wife mentioned her husband's name. Hence Bugis men who are married and have children called as Ambona I Baso, Uwaqna, Puanna, and like the implies the father or father in the family.

A research by Christian Pelras (1996) which is processed into a book The Bugis, managed to uncover the facts about the Bugis life and culture in South Sulawesi. According to Pelras (1996: 5-7), Bugis are known as hard-working people and highly respect the honor, in order to maintain their honor they are

\footnotetext{
* Corresponding author.

E-mail addresses: asri.ismail@gmail.com (Asri Ismail)
}

ISSN : 2597-7385 (Online) - ISLLAC : Journal of Intensive Studies on Language, Literature, Art, and Culture is licensed under Creative Commons Attribution-ShareAlike 4.0 International License (http://creativecommons.org/licenses/BY/4.0/).

54 | ISLLAC : Journal of Intensive Studies on Language, Literature, Art, and Culture 
willing to commit acts of violence. In some sources, Bugis tribes in the pre-Islamic period were largely concerned with status and power (Calldwell, 1995: 410). Behind the harsh nature, the Bugis are also known to be friendly and deeply appreciative of others and very high in their sense of solidarity.

During this time women in order to challenge male dominance has been a lot of resistance movement that has been done. There are several aspects of feminism that be interpreted as a form of protest or resistance. We already know that a woman often deceives her husband by the opposition and not for pleasure, and she may be deliberately acting careless and wasteful because her husband is methodical and stingy (de Beauvoir, 1989: 474).

Kauffman (2003: 84-85) said that in the history and development of feminism theory there are three major waves to prove its resistance. First, early feminists began in the 1800 s. This is the initial foundation of the movement of women who seem to be more busy as women activists. Secondly, in this second wave, it emerged in the 1960s that questioned the representation of female images and everything that was feminist. In this wave arises about the problems of women and the birth of theories of gender equality. Third, in the third wave the emerging theories follow or intersect with contemporary ideas, and then a more pluralistic feminist theory is born. Call it, for example, feminist postmodernism, postcolonial, multicultural, and global. The resistance that women make in demanding the existence of a common existence is a manifestation of deconstruction to obtain equal status with men.

We know that speakers who pay much attention to linguistic speech will tend to use a variety of languages that prism symbolize status and this is seen in women, whereas men are more likely to use words that have the connotation of the working class (hard) (Sumarsono 2002: 115). Such is the way women have been fighting against men over the years by utilizing value systems and knowledge that are distributed through language.

The phenomenon of patriarchy is known as part of the discourse which requires special attention to dismantle how women use language in launching their power in the midst of male domination. Fairclough (1995: 96-97) said that with the illustrative illustrations based on the discourse analysis approach to theoretical positions is an appropriate approach to social and cultural change, since it links the practice, language, and system relationships, including investigation of the nature of social processes and the nature of the language text. Fairclough (1995: 97) emphasized that he adopted three dimensions of the concept of discourse, namely (1) language text (oral or written), (2) the practice of discourse (production and interpretation of the text), (3) sociocultural practice.

This study considers that in class discourse, female teachers practice power with the assumption that teachers have power in the classroom as a structural force between teachers and students in the educational context. Education in dominative culture is directed to situations that place teachers as the only people who know and show science to students who are interpreted as ignorant (Jumadi, 2005: 6). It is a form of domination by teachers over the years.Fairclough (2003: 53) classified three forms, namely: (1) content, ie what is spoken or done, (2) relations, ie social relationships inserted in discourse, (3) subject, the ie position occupied by someone. In the learning activities in the classroom, usually, the teacher always dominates or mastered to perform speech acts (Yanto, Rusminto, \& Tarmini: 2013).

This research is described to analyze the language of Bugis female teachers on the choice of vocabulary seen from the experiential value as part of the text of the vocabulary offered by Fairclough (1989 \& 1995). Vocabulary is the words or terms used in the language produced by the language user. All words produced by language users in their various activities are called vocabulary (Santoso, 2009: 63-64). The vocabulary choices seen from the experiential values include, ideological wording options, the use of words by command mode and prohibitions, the use of Ergative markers, your possessive markers, and clods, the use of the word imperative, the use of conjunctions, the use of the interrogative mode, and use of negation.

\section{METHOD}

This research is a qualitative-interpretative research using the usual critical approach that also calls as the critical paradigm, which is categorized in Critical Discourse Analysis.

This research consists of two things, the first speech in the form of the transcripts of teachers' speech. Secondly is field notes owned by researchers. The main data sources in the study are female teachers from Bugis who teach Indonesian subjects in Class XII IPS 1 and XII IPA 2 in SMA 1 Amali Bone District South Sulawesi, Indonesia. The data collection procedure is done by capturing the data and information required by the procedure as given. (1) video recording, (2) field recording, (3) interviews.

Data analysis phase is done by three stages, namely (1) word reduction. At this stage is done by transcribing data according to the recording, identify the data, classify; (2) data presentation. At this stage, it is done presenting the results of classification in tabular form, presenting the representative data; (3) 
drawing conclusions. At this stage is the last stage with generalizations and search for generalization data. Here are the results of classification.

\section{FINDINGS AND DISCUSSION}

Regarding the use of vocabulary in the Indonesian language who conducted by Bugis female teachers, there are several related issues. Among these are the experiential values, vocabulary values, expressive values, and metaphors. However, in this study, the focus on the experiential value is associated with the content, knowledge, and beliefs of the speaker, in this case, the teacher as a text producer.

The choice of expression vocabulary in Indonesian language learning by female teachers, that are found some things in this research, there are: (1) use the repetitive word with the ideology contains, (2) use the command and ban mode words, (3) use the ergative, possessive,and markers-ko (4) use to the imperatives, (5) use the conjunctions and demonstration markers, (6) use the interrogative mode, and (7) negation.

The results of the study relating to the choice of expression vocabulary values in the vocabulary of Bugis female teachers in Indonesian language study below;

On the repetitive words containing ideology, the vocabulary that appears is the hearing. For the example, (1) Hem-demolo mangkalinga ada is "(Do not want to hear) and on the next sentence (2) Yang dulu mo kita pakai, supaya didengar" (Use the old one, to be heard). Both quotes are suspected to have an emphasis and confidence effect. On the use of word and command mode and prohibition, found several quotes that lead to domination. Below, (1) Eh-maju mako cepat mappuisi (Immediately come to the in front of class to read the poetry), (2)Nda boleh itu, beda kalau SMS (Do not do that, if you sendmessage it will be different), (3)Hai, silakan duduk kalau tidak mau duduk silakan keluar, (Hi, please have a sit if you do not want please go out), (4) Magai iyye, Awal jalan-jalan terusawwe(What happens, Awal only go out side). The citations for students were identified dominating effect.

Meanwhile, regarding the use of your ergative marker, the possessive marker of mu-, and klitik-ko found several sentences in the teacher's dialogue with the students. For example, for your ergative marker, the quote that comes up, (1) Apamukerja di kantin? (What are you doing in the canteen), (2) mukala oki dottoroe (You lost the doctor's handwriting). For the possessive possessive marker the sentence appears (1) Bagaimana kau anumu Wal? (How is your, Wal?), (2) Bajumu, woeanu, Ramadhan Lutfi. (your cloths, Ramdhan Lutfi), (3) Mana bukumu? (Where is your book), (4) Dan, bare engka nilaimu(andyou can get marks), (5)Kondek gemmemu (Your band hair), (6) Kelas tetlluno mampakoe mopa okimu (already in the third grade, your hand writing still like is). Neither with the use of the second person pronoun (Iko) and klitik pemarkah persona (kompletif) -ko. Some of the sentences that appear in the learning, (1) Kenapaiko, Ade? (What happen with you), (2) Ade disitukoe - di dekatnya (Ade, go close to him/her), (3) Eh-maju mako cepat (go fast), (4) Weh Awal bosanku itu liatko jalan terus. (Awal, I am tired look at you go again and again), (5) Nda nda, bilangko di sini (nothing, you are the one who say it is here), (6) Weh Arul nengka jokka-jokkako (Hey Arul, why you hang out), (7) Heh, duduk mako dulu pale (Hey, just have a sit), (8) Iko matu madosa. Abbennna bennako,masseko nanti ujian" (you will get sin if you are mischievous while exam).

Vocabulary choices related to imperative use, a few sentences from the dialogue that comes up, that is (1) Kasih turunki (keep it down), (2) Eh, silakan duduk kalau tidak mau duduk saya silakan keluar, (Hey, just have a sit, if you do not want please go out side), (3) Yang dulumo kita pakai, supaya didengar: Iyye, daripada tidak ada. Silakan naik, (Use the old one, they will listen. Yes, then nothing) (4) Sekarang ee-buka bukuta, belum dapat tugas yang kemarin, (Now, open your book, did get any homework yet?) (5) Nanti pake kertasmi. Ade di situko e-di dekatnya (Later just use paper. Ade, just stay here-near him/her), (6) Heh, duduk mako dulu pale (Hey, just have a sit). Some of sentences are found, among them (1)Iya baru diganti, diganti redaksinya,(Yes it is already replaced, replace the editorial), (2) Bare engkanilaimu(you can get marks). Another case with the use of introgative, also found some features that lead to control, (1) Jadi, eh nda ada lagi yanu,eh Faslam?(So, he is not here Faslam?), (2) Baruki masuk di sini? (Have you entered here recently?), (3) Aga bacana? agabacana yaro? (How can we read, How can we read that?) (5) Kenapa berdiri Riswan? Apadi situ? (Why you are standing Riswan? What is that?), (6) Aga muala mabbeca? (Why you want to be a biker of Beca?). For other word choices in exponential value, ie the use of vocabulary with negation mode. A few quotes are related to the practice of the power of Bugis female teachers, (1) Hai Hai jangko pakai bahasa Bugis narekamki itu anue (Hi do not use Bugis language, we are being recorded), (2) Ndaboleh nyontek (Do not copy), (3) Eh-nanti kalau jam terakhir jangko langsung pulang ya (Later if the last periode already over, do not go home), (4) Eh-segala macam, sembarang. Ndada. (Hey, it's up to you), (5) Jangan ada yang sama, (Do not be same) (6) Eh hapus itu "dan" nda boleh, (Eh, delete it "and" can not).

56 | ISLLAC : Journal of Intensive Studies on Language, Literature, Art, and Culture 
According to the above data, the choice of vocabulary found in the teacher's speech will not be discussed in its entirety, but only a few of the following sections represent the following, according to the data exposition.

\section{Reflecting Compelling Vocabulary}

The commonly used vocabulary in the recording of female Bugis teacher's speeches is "dengar". Heard is used by the subject to emphasize an instruction. The use of repeated word choices can be seen from the following example of the speech:

(1) Hem-demolo mangkalinga ada (Does not want to hear)

(2) Yang dulumo kita pakai, supaya didengar(Use the old one, so it can be heard)

The choice of hearing words in speech (1) is meant by the subject that the student is stubborn or naughty. This sentence comes after the impact that students get because they do not want to obey the command of the teacher. While the choice of hearing the word in speech (2) is actually intended to read command speech, but this sentence is lost because students understand the wishes of teachers. Speech (2) is implicitly meant that it is not a matter of reading a speech the teacher has ever examined before, most important that all his classmates can listen directly to how to read it.

Sentences (1) and (2) are interpreted, discourse makers want to convince partners to say that what is being said is true. In the speech, the teacher does not use compromise statements, such as she said or if it can be a persuasive weakening because it is considered less able to convince the partner (who are listen/hear of her).

Basically an attempt to convince others of what we said is one of the attempts to manifest power and domination, because that power and domination can manifest itself if what we said can be transformed into the correct argument for a person. Santoso also said the same thing (2009: 26) assertion that the language of women is the accumulation of a struggle for a strong, central, and superordinate place.

\section{Vocabulary Dominates Effects With Command and Prohibition Modus}

There are several vocabulary options that teachers use as a guide to the effects of domination. The use of the vocabulary can be seen in the following sentence.

(3) Eh-maju mako cepat mappuisi (Hey, go fast to read the poetry)

(4) Hai, silakan duduk kalau tidak mau duduk saya silakan keluar (Hi,have a sit if you do not want, please go)

(5) Magai iyye, Awal jalan-jalan terus awwe(What happen, why Awal always go out)

In the conversations (3), (4), (5) there is a very striking aspect of the use of command mode and prohibitions that are marked with maju mako,silahkan, and magai iyye. This gives the impression that the subject in the conversation is to dominate the opponent speech is done without control so that students easily do what the command and prohibition.

In the sentence (3) the teacher firmly rules the students who have not read the poem in front of the class. By using advanced sentence maju mako. The teacher doea not given an opportunity to defend in the context in question. Only, in a sentence (4) the teacher does the dominance by using the word kalau tidak interpreted as a requirement. This condition is a manifestation of teacher control and restriction. While in a sentence (5) the teacher uses a subtle way of giving prohibition to the students. It appears to be the absence of the word jangan atau awas, but the teacher's argument mean prohibition. Prohibition for not to walk while the class start.

Of the three vocabulary (1), (2), and (3) it appears that in the classroom, the teacher does the domination in the classroom. It should be noted that the subject dominated the student by control and a subtle way is a form of command mode and prohibition because it has power over other participants. With much of the argument, students feel uncomfortable in learning. This is because the classroom atmosphere is tense and there is no pleasant interaction (Yanto, Rusminto, \& Tarmini: 2013: 1).

\section{Vocabulary Dominating Effect with the Use of Ergative Markers - $m u$, Positional Marker - mu and Other Persona Markers}

There are several choices of words used by Bugis female teachers in launching the dominant power practice. The choice of words in question is the words with Ergative markersmu-in advance, the possessive marker $m u$-andthe other personality marker. This can be seen from the following speech.

(6) Apa mukerja di kantin? (What are you doing in the canteen)

(7) Mukala oki dottoroe (You defeat the doctor's hand writing)

(8) Dan, bare engka nilaimu (and you can get your marks)

(9) Kondek gemmemu(Your band hair) 
In the (6) and (7) sentences the teacher uses the greeting with the ergative markermu- on the word mukerja (you do) and mukala (you defeat), and the second greeting uses possessive markermu- on word nilaimu(your value) and gemmemu (your hair). The second person's greeting with possessive-muand ergative $m u$ - are usually directed at people who are easier than speakers or in lower degrees. Thus, there appears to be a dominant effect that teachers do to students. Communication between teachers and students is very clear that teachers have structural power so that teachers have the freedom to say anything to the students. Likewise with some follow-up sentences that call the student's name directly.

Based on the cultural order of Bugis society, Sipkatau culture "mutual respect and mutual respect is highly upheld since the first." One of the clear evidence shown is the abstinence for Bugis women to call her husband's name directly. When that happens, women are considered not to know the etiquette of communicating. Likewise with social communication done, especially against people who are more respected without mentioning the greeting and title, has become a habit that is difficult to remove.

However, what happened in the Bugis women's conversation in a class with their students seemed to contrast and contrary to the tradition held. As Mahmud (2009: 28) said that women always pay attention to aspects of modesty in communicating. It became one of the proofs that Bugis women have exercised power in the realm of education.

In addition, the effect of dominance can also be seen in the use of the choice of a greeting with other personality markers.

(10) Iga lo paddongo-dongokoiko mato lo paddongo-dongo alemu (Who made you as a fool person, your own self alreadymade you fool)

(11) Kenapaiko, Ade? (What happen with you, Ade?)

(12) Heh, duduk mako dulu pale(Hey, just have a sit)

The choice of Ikopada (10), the clan aspect of the incomplete -ko marker of speech (11) and (12) indicates the speaker's social identity has power over the opponent of speech. The reason, the incomplete choice of words and markers in the Bugis culture is considered polite when used for people of equal or above the speaker. Nowadays, Iko is considered to have a very inhuman taste value. Given the choice of words, proving that teachers perpetuate power with a variety of vocabulary that dominate the effect.

\section{Vocabulary Dominance Effect Use The Imperative Markers}

Utilization of vocabulary with imperative marker can be seen from some of the following utterances.

(13) Kasih turunki (keep it down)

(14) Sekarang ee - buka bukuta, belum dapat tugas yang kemarinkan?(ta: us: you)

(15) Yang dulumo kita pakai, supaya didengar (we use, to be heard)

Vocabulary choices in speech (13), (14), and (15) express imperative sentences of commands to do something. The imperative sentence is used by the teacher to show the teacher's position above the student. The suffix - ki imperative marker in the word turunki from speech (13) which means, in the context of Bugis culture, is considered very polite compared to using the word $k o$. In speech (14), the sentence marker is persona -ta, which means us. But in the context of Bugis culture, we are just like you, the first person singular. The word marker persona is considered the most polite to use. Meanwhile, in the speech (15), the 'affectionate' suffix-mo is an imperative form of command which is considered to have a negative sense rather than using a suffix-mi.

The order shows an expansionary relationship between teacher and student. The teacher seemed to impose the will on all three quotations. It's just that in speeches (13) and (14) is done subtly, unlike speech (15). The implication of the use of the imperative command marker is the form of power and domination practice against the opposite argument because such an order can only be done by the authority holder against his subordinates. Foucault's view that which makes a lasting or acceptable power is due to power not only gives space to say "no", but power passes and produces something, engenders pleasure, shapes knowledge, and produces discourse (Jorgensen \& Phillips, 2007: 25).

\section{Controlling Effect Vocabulary}

The vocabulary options in class discourse that are used to control the participants are found in several word forms, among others; (1) use of conjunction, (2) use of introgative form, (3) use of negation form. The use of these three forms can be seen in the following data.

(16) Iya baru diganti, diganti redaksinya (Yes it is already replace, replace the editorial)

(17) Bare engkanilaimu. (you can get marks)

(18) Iyye,kenapai? Iya baru diganti, diganti redaksinya (Yes, what happen? Yes it is already replace, replace the editorial) 
(19) Aga bacana? agabacana yaro? (How to read, how to read that?)

(20) Hai-jangko pakai bahasa Bugis narekamki itu anue (Hey, do not use Bugis language, we are being recorded)

(21) Jadi, eh nda ada lagi yanu,eh Faslam?(So, no more Faslam?)

The use of conjunctions iya and bare engka (in existence) in speeches (16) and (17), is used to affirm and explain the content of messages to be conveyed to participants. This affirmation aims to control the speech so that it can be understood by its speech partner (student). Meanwhile, in speech (18) using the imperative mode of achievement using the suffix- $i$ is considered the teacher's strategy by reason of decency in asking. Similarly in speech (19), it uses the introgative mode of aga (what). Thus, speeches (18) and (19) aim to control what the teacher wants can be directed. It is regarded as a way for the other person to answer from the questions as the content of the desired message.

The forms of negation in speech (20) and (21) are marked with the jangko (Do not do) and nda ada (not) empowered to affirm the effect of controlling the speech in order to straighten out what the speaker wants. As Sudaryono (1992: 1) narrates, the negation can mean cancellation, rejection, or omission that will determine the follow-up of the communication undertaken. Thus, the interpretation becomes one of the determinants as well as forming the meaning of speech.

Based on the explanation of the research results, there are 7 vocabulary expression vocabulary options included in the practice of the Bugis female teacher's power in Indonesian language learning which includes the use of words containing ideology, the use of words by command mode and prohibitions, the use of Ergative markers $m u$-, possessive markers - $m u$, and klitik-ko, the use of imperative words, the use of conjunctions, the use of the interrogative mode, and the use of negation.

The use of vocabulary seen from the experiential value found the use of vocabulary with convincing effect, vocabulary effect domination, and vocabulary effect of control. Vocabulary that is utilized to convince the said partner, namely: vocabulary hear. Vocabulary options for dominance are found in use of command mode and prohibitions, use of ergative markers, possessive markers, use of complete markers, use of second person pronouns, imperative use. The participant control is found in the use of conjunctions, the use of the integrative form, and the use of negation forms. Jumadi (2005: 6) says that education in dominative culture is directed to situations that place the teacher as the only person who knows and shows science to students who are interpreted as ignorant.

The use of dengar vocabulary is utilized by discourse makers to convince partners to say that what is being said is true. In the speech, the teacher does not use compromise statements, such as katanya or kalau bisa a persuasive weakening because it is considered less able to convince the said partner. After all, the word katanya or kalau bisa show that what the speaker is saying does not have a strong foundation. That is why power is never going away from knowledge. Power is exercised not solely through struggle, restriction, or prohibition, but management: energy management, ability, and community life where knowledge is the foundation (Haryatmoko: 2014: 246).

The vocabulary that dominates the effect utilized by the teacher is found in the use of advanced word maju mako, silakan, and magai iyye. This gives the impression that the subject in the conversation is dominating the opponent of the speech that is done without control so the students easily do what the command and prohibition. In the use of the ergative marker $m u$-, possessiveness-mu, kompletif $-k o$, and the use of the second person's word iko (you) denotes the dominance of the opponent. This is closely related to the social life of the Bugis society that influences the use of language, especially in the form of greetings. Conventionally, in Bugis society, the relationship between the community is arranged in the form of greetings in accordance with etiquette.

According to the procedures inpenngadereng(handling the ship), Mattulada (1985: 439) explains that in the meeting of the king arranged in such a way with very strict order including behavior and speech that must be maintained. This has implications for the speech ordinances of people in the outer community not to use the word $i k o$ (you), but using $i d i q$ (you). Similarly applicable to talk with the other person who is in a position lower or younger than his partner said, he must use the word idiq(you). Please note, in terms of language politeness, greeting $i k o$ (you) is considered polite and ethical, so that only used by certain people who want to do domination or show power. Similarly with the ergative marker $m u^{-}$, possessive $m u$ and complete- $k o$, the value markers are the same as risks. It can only be done by a group that has a dominant position and power over authority.

In addition, the choice of vocabulary in class discourse that is used to control the participants is found in several word forms, such as the use of conjunctions, interrogatives, negations by the teacher as a speaker. The use of conjunctions is used to control the teacher. It is intended that speakers are able to direct the students as desired and clarify the necessary understanding traffic. In addition, the use of an interrogative form to control the directional speech of the questions asked by the speaker. In addition, 
found an interrogative form that is used to understand the seriousness of the opponent said. Meanwhile, the form of negation that teachers use in class discourse is used to impose restrictions on all student behavior, thus giving the impression that what the teacher does not want is the truth. This is in line with Fairclough's (1995) statement that a number of restrictions imposed on participants are those forms of control and restrictions according to the type of discourse used.

\section{CONCLUSIONS}

Based on the explanation of the results and discussion, are seven important things from the vocabulary choices used by the teacher in an experiential value, there are the choice of words containing ideology, the use of the word with the mode of command and prohibition, the use of Ergative markermu-, possessive marker - $m u$, and markers- $k o$, use of imperative words, use of conjunctions, use of the interrogative mode, and the use of negation. All of these lead to the practice of power and domination by Bugis female teachers in class discourse. Thus, the prevalence of patriarchal practices prevailing within the Bugis society has been deconstructed by female with resistance in the education sphere. Bugis female who work as teachers were also doing power practice using a language container. This is contrary to the prevailing manners of Bugis society which judge female to have the decency and ethics of communicating.

The implication of the findings of this study in learning Indonesian, which can be input and consideration in learning related to learning discourse and speaking skills. Furthermore, this research shows that gender ideology in the context of power, an important understanding that Bugis female teachers are able to perform power practices in the learning process of Indonesian language that uses a mixture of Bugis language introduction.

\section{REFERENCES}

Calldwell, Ian. 1995. Power, State, and Society Amon The pre-Islamic Bugis. Terjemahan Online (http://www.oxis.org/terjemahan/kuasa.pdf). Halaman 394-421 diakses tanggal 22 September 2017.

Calldwell, Ian. 1995. Power, State, and Society Amon The pre-Islamic Bugis. Terjemahan Online (http://www.oxis.org/terjemahan/kuasa.pdf). Halaman 394-421 diakses tanggal 22 September 2017.

de Beauvior, Simone. 1989. Second Sex: Kehidupan Perempuan. Terjemahan Toni B. Febriantono \& Nuraini Juliastuti. 2016. Yogyakarta: Pustaka Promethea.

Fairclough, N. 1989. Language and Power ;Relasi Bahasa, Kekuasaan, dan IdeologiTerjemahan Indah Rohani.2003. Malang: Boyan Publishing.

Fairclough, N. 1995. Critical Discourse Analysis; Critical Studies of Language. New York: Longman Group UK Ltd.

Fairclough, Norman. 2003. Languange and Power. England: Longman Group UK. Terjamahan oleh Rohmani Indah. 2003. Relasi, Bahasa, Kekuasaan, dan Ideologi. Malang; Boyang Publishing.

Foucault, Michael. 1980. Wacana Kuasa/Pengetahuan (Power/Knowledge). Translated byYudi Santoso. 2017. Yogyakarta: Narasi-Pustaka Promethea.

Gay, M., \& Susanti, P. A. (2017). Taboo Language Within Ternate Society: A Study on its Formation and Reference. ISLLAC : Journal of Intensive Studies on Language, Literature, Art, and Culture, 1(1), 170183.

Haryatmoko. 2014. Etika Politik dan Kekuasaan (Ethics of Politics and Power). Jakarta: PT Kompas Media Nusantara.

Jumadi. 2005. Representasi Power dalam Wacana kelas (Kajian Etnografi Komunikasi di SMA 1 Malang). Disertasi tidak diterbitkan. Malang: Pascasarjana UM.

Kauffman, Linda. 2003. Teori Feminisme. In Gadis Arivia (Ed), Filsafat Perspektif Feminis (hlm.81-157). Jakarta Selatan: SMK Garfika Desa Putera.

Mahmud. 2009. Kedudukan dan Fungsi Elong Ugi (Position and Function Elong Ugi). Ujung Pandang: Pesantren.

Mattulada.1995. Latoa: Suatu Lukisan Analitis terhadap Antropologi Politik Orang Bugis (Latoa: An Analytical Painting of Political Anthropology of the Bugis). Ujung Pandang: Hasanuddin University Press.

Pelras, Christian. 1996. The Bugis.Terjemahan Abdul Rahman Abu, Hasriadi, \& Nurhadi Simorok. 2006. Jakarta: Nalar bekerjasama dengan Forum Jakarta-Paris.

Santoso, Anang . 2009. Bahasa Perempuan: Sebuah Potret Ideologi Perjuangan (Woman Language: A Portrait of the Ideology of Struggle). Jakarta: PT Bumi Aksara.

60 | ISLLAC : Journal of Intensive Studies on Language, Literature, Art, and Culture 
Syamsudduha. 2014. Dimensi Kewacanaan Pappaseng: Kajian Wacan Kritis (Dimension of Pappaseng Discrimination: Critical Discourse Review). Disertasi tidak diterbitkan. Makassar: Pascasarjana UNM.

Sumarsono. 2002. Sosiolinguistik. Yogyakarta: Pustaka Pelajar.

Thomas, Linda dan Wareing, Shan. 1999. Language, Society, and Power. New York: Routledge. Translated by Prof. Abd. Syukur Ibrahim. 2007. Yogyakarta: Pustaka Pelajar.

Yanto, Rusminto,\& Tarmini. 2013. Representasi Kekuasaan pada Tindak Tutur Guru dalam Pembelajaran Bahasa Indonesia (Power Representation on Teaching Speech in Teachers Bahasa Indonesia). Jurnal J-Simbol (Bahasa, Sastra, dan Pembelajarannya). Vol: 1. No. 2.

61 | ISLLAC : Journal of Intensive Studies on Language, Literature, Art, and Culture 